\title{
Increased phosphorylation of focal adhesion kinase in diabetic rat kidney glomeruli
}

\author{
S. Clark, E. Muggli, N. La Greca, M. E. Dunlop \\ Department of Medicine, University of Melbourne, Victoria, Australia
}

Summary Altered extracellular matrix production by the glomerular mesangium is a feature of diabetes mellitus. Matrix proteins, including fibronectin, via interaction with cell-surface receptors (the integrins) may activate intracellular pathways such as prostaglandin production, shown previously to be stimulated by addition of fibronectin to glomerular cores. However, the signalling pathways involved are unclear. An intracellular tyrosine kinase (focal adhesion kinase), associated with focal adhesions, is known to be phosphorylated after interaction with matrix proteins. We now show for the first time, in glomeruli from diabetic rats, that focal adhesion kinase has increased phosphorylation on tyrosine, when compared with non-diabetic control rats. This phosphorylation was labile and disappeared with extended time of sample preparation or digestion of glomeruli to glomerular cores. Cultured mesangial cells, from non-diabetic rats, plated onto fibronectin also showed increased tyrosine phosphorylation of focal adhesion kinase accompanied by a twofold increase in prostaglandin production. However, it may not be possible to replicate fully the diabetic "state" in vitro merely by use of raised glucose concentrations, as these conditions (for 3 weeks) resulted in decreased focal adhesion kinase phosphorylation, despite increased fibronectin and prostaglandin levels. A role for increased focal adhesion kinase phosphorylation in kidney glomeruli isolated from diabetic rats, and any linkage to intracellular signalling pathways remains to be determined. [Diabetologia (1995) 38: 1131-1137]

Key words Diabetes mellitus, focal adhesion kinase, glomeruli, prostaglandins, fibronectin.
Altered elaboration of the glomerular extracellular matrix (basement membrane and mesangial matrix) has been widely reported in diabetes mellitus and may influence both cell/matrix interactions and biochemical pathways (including increased prostaglan-

Received: 3 October 1994 and in revised form: 8 March 1995

Corresponding author: Dr. S. Clark, University of Melbourne, Department of Medicine, P.O. Royal Melbourne Hospital, Victoria 3050, Australia

Abbreviations: FAK, Focal adhesion kinase; STZ, streptozotocin; DMEM, Dulbecco's modified Eagle's medium; HRP, horseradish peroxidase; ABTS, 2,2'-azinodi-3-ethylbenzthiazoline sulfonic acid; $\mathrm{PGE}_{2}$, prostaglandin $\mathrm{E}_{2}$; PMSF, phenylmethanesulphonyl fluoride; FCS, fetal calf serum; ECL enhanced chemiluminescence; PVDF, polyvinylidene difluoride. din production) that contribute to deteriorating kidney function. In tissue from long-term diabetic patients [1] and from mesangial cells (human or rat) cultured under high glucose concentrations [2-4], changes to the extracellular matrix can be demonstrated including increased production of fibronectin, laminin and type IV collagen. The increase in mesangial matrix probably contributes to the structural changes observed in the diabetic kidney, however, the effect of matrix proteins on cellular function may also be important and must be considered. One of the early biochemical changes to occur in the diabetic kidney is the increased production of prostaglandins [5], shown by previous studies to be consequent on hyperglycaemia-induced protein kinase $\mathrm{C}$ activation [6-8], and we have shown, in vitro, that the addition of exogenous fibronectin to glomerular 
cores or isolated mesangial cells also results in increased production of prostaglandins [8]. Matrix proteins, including fibronectin, signal to cells via transmembrane cell surface receptors (integrins). However, the signalling molecules linking activated integrins to subsequent biochemical events are not clearly understood.

Focal adhesions are specialised regions found at cell borders where bundles of actin fibres terminate; they contain structural proteins (including paxillin, talin, tensin, vinculin), kinases (including pp60 $0^{\text {stc }}$ and protein kinase C) plus other components $[9,10]$. In addition, certain integrins, including the $\alpha_{5} \beta_{1}$ fibronectin receptor, are recruited to areas of focal adhesion $[11,12]$. The recent demonstration of a cytosolic tyrosine kinase (focal adhesion kinase [FAK] $M_{r}$ $125 \mathrm{kDa}$ ) in focal adhesions, which shows increased tyrosine phosphorylation and kinase activity when cells are plated onto fibronectin $[13,14]$, could provide a mechanism to link fibronectin ligation (via $\beta_{1}$ integrins) with intracellular signalling such as stimulation of pathways resulting in increased prostaglandin production. However, whether signals generated by extracellular matrix components such as fibronectin can be transduced via focal adhesions remains unknown. As fibronectin is increased in diabetes we investigated, in kidneys from diabetic rats, alterations in intracellular pathways known to be linked to fibronectin. We initially chose to investigate the phosphorylation state of FAK in glomeruli isolated from streptozotocin-induced diabetic rats. Similar studies were conducted with cultured mesangial cells grown in high or low concentration glucose medium and, in addition we measured the response of FAK to fibronectin.

\section{Materials and methods}

Monoclonal antibody $2 \mathrm{~A} 7$ (generated against phosphorylated p125 protein [15]) was generously provided by Dr. T.Parsons (University of Virginia, Charlottesville, Va., USA). Antibody PY20 (antiphosphotyrosine) was from ICN (Seven Hills, NSW, Australia), rabbit anti-mouse antiserum from Dako (Carpinteria, Calif., USA) and prostaglandin $\mathrm{E}_{2}\left(\mathrm{PGE}_{2}\right)$ antiserum from Advanced Magnetics (Cambridge, Mass., USA). ${ }^{3} \mathrm{H}-\mathrm{PGE}_{2}$ and enhanced chemiluminescence (ECL) reagents were from Amersham International (Amersham, Bucks, UK), plasma fibronectin from Promega (Rozelle, NSW, Australia) and rabbit anti-fibronectin antiserum from Calbiochem (La Jolla, Calif., USA). Cellular fibronectin and all other chemicals were from Sigma Chemical Co. (St. Louis, Mo., USA).

Induction of diabetes. Diabetes was induced in male Sprague Dawley rats (weighing approximately $200 \mathrm{~g}$ ) by a single intraperitoneal injection of streptozotocin (STZ) at $70 \mathrm{mg} / \mathrm{kg}$ in $100 \mathrm{mmol} / 1$ trisodium citrate $\mathrm{pH} 4.0$ [16]. Establishment of diabetes was confirmed by urinary glucose analysis $48 \mathrm{~h}$ after injection. Diabetes was maintained for 3 weeks before commencement of the experiments. At this time STZ diabetic rats weighed approximately $70 \%$ of control animals. Blood glu- cose levels were $19 \pm 1.3 \mathrm{mmol} / 1$ in STZ-diabetic rats and $5.1 \pm 0.4 \mathrm{mmol} / 1$ in control animals.

Preparation and culture of rat renal glomeruli and mesangial cells. Glomeruli were prepared from control and diabetic rats by differential sieving of kidney cortex through 250 and $125 \mu \mathrm{m}$ sieves and collection on a $75-\mu \mathrm{m}$ sieve as described previously [16]. All buffers used in the preparation contained $250 \mu \mathrm{mol} / 1$ vanadate $\left(\mathrm{VO}_{4}\right)$ or pervanadate $\left(\right.$ perVO $\left.\mathrm{V}_{4}\right)$ except where noted. Unless otherwise stated the time for preparation of glomeruli ranged between 20-25 min. Approximately $10,000-15,000$ glomeruli were isolated from each rat kidney with no significant difference between control and STZ-diabetic rats. Glomerular cores were prepared by digestion of intact glomeruli with $0.5 \mathrm{mg} / \mathrm{ml}$ collagenase type $\mathrm{V}$ for 10 $30 \mathrm{~min}$ at $37^{\circ} \mathrm{C}$. The digested cores were then centrifuged at $100 \mathrm{~g}$ for $8 \mathrm{~min}$ before solubilisation or plating as described below. Immediately following preparation glomeruli or glomerular cores were solubilised in lysis buffer (in mmol/l: $150 \mathrm{NaCl}$, 50 Tris, pH 7.5, 2 EGTA, $1 \mathrm{VO}_{4}, 1 \%$ Triton X-100, $0.25 \%$ deoxycholate, 0.15 unit of aprotinin $/ \mathrm{ml}, 10 \mu \mathrm{g} / \mathrm{ml}$ leupeptin and $1 \mathrm{mmol} / \mathrm{l}$ phenylmethylsulphonyl fluoride [PMSF]), freeze/thawed three times and rotated for $1 \mathrm{~h}$ at $4^{\circ} \mathrm{C}$. After clarification of the lysate by centrifugation at $10,000 \mathrm{~g}$ for $10 \mathrm{~min}$ at $4{ }^{\circ} \mathrm{C}, \mathrm{FAK}$ was immunoprecipitated as described below. Where used, perVO ${ }_{4}$ was generated by mixing equal concentrations of $\mathrm{VO}_{4}$ and $\mathrm{H}_{2} \mathrm{O}_{2}$ (final concentrations $5 \mathrm{mmol} / 1$ ), incubation for $15 \mathrm{~min}$ at $22^{\circ} \mathrm{C}$ then addition of $200 \mu \mathrm{g} / \mathrm{ml}$ catalase. This solution was used immediately.

Mesangial cells were grown out from explanted glomerular cores as described previously [8] and maintained in Dulbecco's modified Eagle's medium (DMEM) containing $20 \%$ (v:v) fetal calf serum (FCS); cells were used between passages one and four. Cells were lysed by direct addition of $\mathrm{VO}_{4}$-containing lysis buffer onto the tissue culture dish, after $5 \mathrm{~min}$ on ice the lysate was centrifuged at $10,000 \mathrm{~g}$ for $10 \mathrm{~min}$ at $4^{\circ} \mathrm{C}$. In some experiments dishes were coated with $50 \mu \mathrm{g} / \mathrm{ml}$ plasma fibronectin overnight at $4{ }^{\circ} \mathrm{C}$ followed by two washes in phosphate buffered saline (PBS) before blocking in $2 \mathrm{mg} / \mathrm{ml}$ bovine serum albumin (BSA) for $1 \mathrm{~h}$ at $37^{\circ} \mathrm{C}$. Mesangial cells $\left(5 \times 10^{5}\right)$, dissociated in trypsin/versene were added to the fibronectin-coated plates in DMEM containing $2 \% \mathrm{FCS}$ for $2 \mathrm{~h}$ at $37^{\circ} \mathrm{C}$. At the end of the incubation period the medium was removed and stored for PGE measurements and the adherent cells lysed as described above.

Immunoprecipitation and immunoblotting of FAK. FAK was immunoprecipitated from glomerular or cell lysates, equalised for protein content, by incubation at $4^{\circ} \mathrm{C}$ overnight with antibody $2 \mathrm{~A} 7(2-5 \mu \mathrm{l})$ coupled to rabbit anti-mouse antibody $(5 \mu \mathrm{l})$ pre-bound to protein A sepharose $(20 \mu \mathrm{l})$. After washing the immunoprecipitates in PBS containing $0.2 \%$ Triton $\mathrm{X}$ 100 , proteins were separated by SDS-PAGE $(7.5 \% \mathrm{w} / \mathrm{v}$ acrylamide). Proteins were transferred to polyvinylidene difluoride (PVDF) membranes in Towbin buffer (25 mmol/1 Tris, pH 8.3, $192 \mathrm{mmol} / \mathrm{l}$ glycine, $20 \%$ methanol) in the absence of SDS and probed with either antiphosphotyrosine (PY20, $1: 5000$ ) or anti-FAK $(2 \mathrm{~A} 7,2.5 \mu \mathrm{g} / \mathrm{ml})$ antibody and detected by ECL. In some experiments aliquots of cell lysate $(100 \mu \mathrm{g}$ protein) were separated by SDS-PAGE without prior immunoprecipitation.

Measurement of prostaglandins. E-series prostaglandins (PGE) are the major eicosanoid metabolites formed by mesangial cells. Therefore, total immunoreactive PGE activity was measured by specific RIA, in the incubation medium of mesangial cells as described previously [8]. 
Measurement of fibronectin. Ninety-six-well ELISA plates were incubated with either $100 \mu \mathrm{l}$ sample or $100 \mu \mathrm{l}$ cellular fibronectin standard $(0-100 \mathrm{ng})$ overnight at $4^{\circ} \mathrm{C}$. The plates were blocked with $1 \%$ BSA in PBS $/ 0.5 \%$ Tween 20 for $1 \mathrm{~h}$ at $37^{\circ} \mathrm{C}$ then washed once in $0.9 \% \mathrm{NaCl} / 0.5 \%$ Tween 20 , before addition of anti-fibronectin antibody $(1: 2500)$ in PBS/0.5\% Tween 20 for $1 \mathrm{~h}$ at $37^{\circ} \mathrm{C}$. Plates were washed four times and then incubated with horseradish peroxidase (HRP)-conjugated goat anti-rabbit $(1: 2000)$ for $20 \mathrm{~min}$ at $22^{\circ} \mathrm{C}$. After washing four times the plates were developed with $2,2^{\prime}$-azinodi-3ethylbenzthiazoline sulfonic acid (ABTS) for $20 \mathrm{~min}$ and read at $405 \mathrm{~nm}$.

Fibronectin (matrix plus cell-associated) from mesangial cells grown in DMEM/20\% FCS containing 5.6 or $25 \mathrm{mmol} / 1$ glucose for up to 3 weeks, was extracted in $2 \mathrm{~mol} / \mathrm{l}$ urea/ $20 \mathrm{mmol} / \mathrm{l}$ Tris pH 7.5, as described previously [2] and diluted $1: 10$ in this extraction buffer for assay. Acute fibronectin production from the above cultures was measured as medium content over $24 \mathrm{~h}$ under serum free $(0.1 \% \mathrm{BSA})$ conditions. Medium was diluted 1 : 40 in DMEM/0.1\% BSA and added directly into the assay.

Protein measurements. The protein content of glomerular, glomerular core and mesangial cell lysates was assayed with Coomassie Brilliant Blue dye [17].

\section{Statistical analysis}

Numerical results are expressed as the mean \pm SEM and statistical comparisons were performed by Student's $t$-test for unpaired samples, $p$ less than 0.05 was taken as significant.

\section{Results}

FAK could be immunoprecipitated from either control or diabetic glomeruli with the specific antibody 2A7 after separation of proteins by SDS-PAGE (Fig. 1B). In all experiments, including the representative experiment shown (Fig. $1 \mathrm{~A}$ ), FAK was strongly phosphorylated only in the diabetic glomeruli. Digestion of glomeruli, with collagenase, to produce glomerular cores resulted in loss of FAK tyrosine phosphorylation (Fig. 1A). There was, however, no significant difference in the level of FAK protein in any of the samples (Fig.1B). Over a series of experiments, containing between one and five replicates (either pooled glomeruli or glomeruli from individual animals) significant tyrosine phosphorylation of FAK was observed in diabetic glomeruli in six of six experiments. However, in general there was no phosphorylation of FAK immunoprecipitated from control glomeruli (four of six experiments) or, where it was observed, at a very low level (two of six experiments) when compared with diabetic glomeruli.

Focal adhesions (the cellular location of FAK) are reportedly difficult to detect in vivo [10] probably due to their tenuous nature in living tissues. We observed that the tyrosine phosphorylation of FAK in diabetic kidneys was readily lost either by disruption of the kidney glomerulus in order to produce glomer-
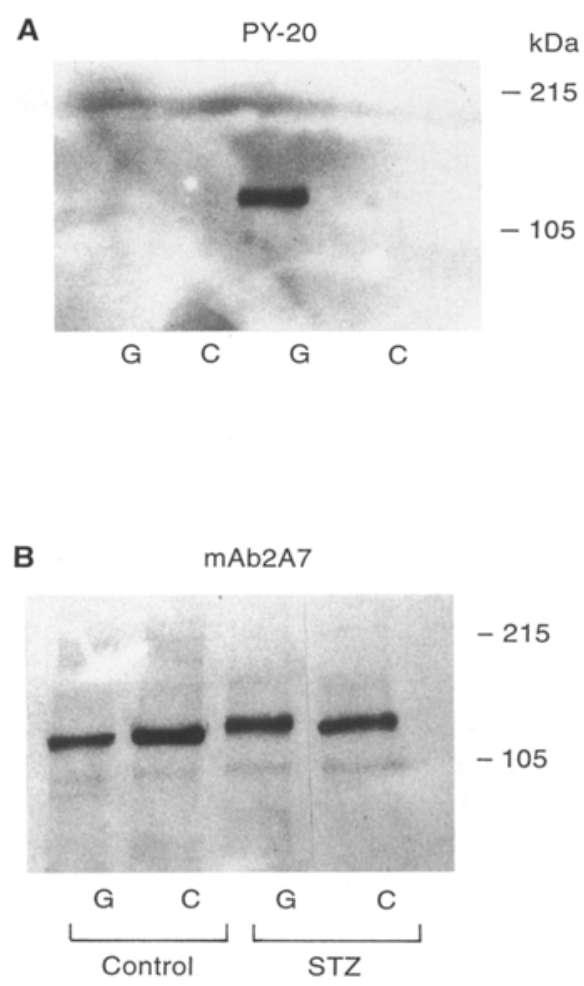

Fig. 1. (A, B) Identification of FAK in isolated glomeruli (G) or glomerular cores (C) from control and diabetic (STZ) rats. FAK was immunoprecipitated from lysates of approximately 20,000 glomeruli and proteins resolved on $7.5 \%$ SDS-PAGE. Samples were probed with antibody PY20 against phosphotyrosine (A) or antibody $2 \mathrm{~A} 7$ against FAK (B). Results are representative of at least six individual experiments

ular cores (Fig. 1 A) or when there was some delay in preparation of the glomeruli (Fig.2). In the experiment shown in Figure 2 glomeruli were prepared from individual rats and lysed immediately after sieving approximately $20 \mathrm{~min}$ (lanes $1,3,6,8$ ), or $28 \mathrm{~min}$ (lanes 2, 4, 7, 9) or 34 min (lanes 5, 10) after removal from the animals. Only diabetic glomeruli prepared at the earliest time $(20 \mathrm{~min})$ showed tyrosine phosphorylation of FAK (Fig. 2, lanes 6, 8). To determine if tyrosine phosphatase(s) were responsible for this lability and if blocking these phosphatases would result in FAK phosphorylation in control glomeruli, experiments were conducted in the presence or absence of either $\mathrm{VO}_{4}$ or its more active and readily cellpermeable form perVO $\mathrm{O}_{4}$. Figure 3 indicates that both $\mathrm{VO}_{4}$ (lane 4) and perVO (lane 6) maintain FAK phosphorylation in glomeruli isolated from diabetic rats, whilst in the absence of phosphatase inhibition phosphorylated FAK was not observed (lane 2). However, the addition of perVO ${ }_{4}$ did not result in the appearance of phosphorylated FAK in control preparations (Fig. 3, lane 5) suggesting that differential activity of phosphatases is not responsible for the observed differences between control and diabetic rats. 
Phosphotyrosine

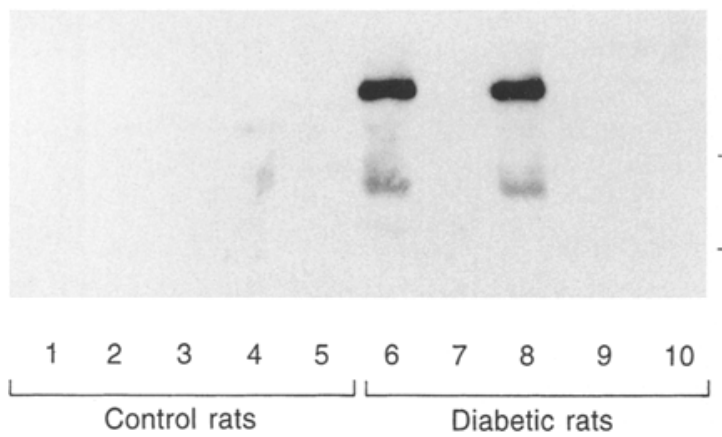

Fig.2. The effect of preparation time on detection of phosphorylated FAK in control (lanes 1-5) and STZ diabetic (lanes 6-10) rats. Glomeruli were lysed approximately $20 \mathrm{~min}$ (lanes 1, 3, 6, 8), 28 min (lanes 2, 4, 7, 9) or 34 min (lanes 5, 10) after removal from the animals. Each lane represents glomeruli isolated from both kidneys of an individual rat. FAK was detected with antiphosphotyrosine antibody (PY20) after immunoprecipitation and separation by SDS-PAGE. Results are representative of two individual experiments

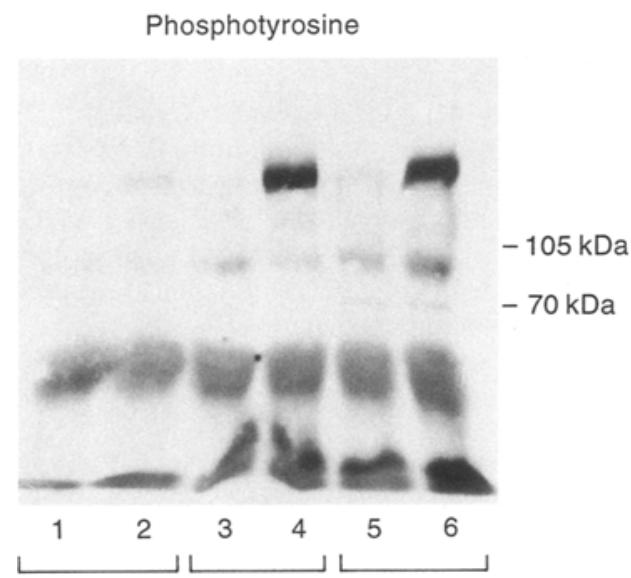

Fig. 3. The effect of inclusion of $\mathrm{VO}_{4}$ and perVO $\mathrm{V}_{4}$ on detection of phosphorylated FAK in glomeruli isolated from control (lanes 1, 3, 5) and STZ diabetic (lanes 2, 4, 6) rats. Glomeruli were isolated and solubilised either in the absence of phosphatase inhibitors (lanes 1,2) or in the presence of $250 \mu \mathrm{mol} / 1 \mathrm{VO}_{4}$

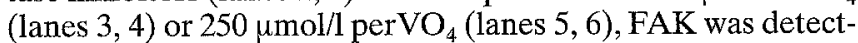
ed as described in Figure 2. Results are representative of two individual experiments

To examine whether the increased phosphorylation of FAK in diabetic glomeruli was specific, we analysed total glomerular lysates for phosphotyrosine-containing proteins. In general the glomeruli isolated from diabetic rats showed higher levels of tyrosine phosphorylation than controls. Major species were observed at apparent molecular weights of $150 \mathrm{kDa}, 115 \mathrm{kDa}, 105 \mathrm{kDa}, 90 \mathrm{kDa}$ and between $50 \mathrm{kDa}$ and $60 \mathrm{kDa}$ (Fig.4). After digestion of glomeruli to glomerular cores there was a generalised loss of phosphotyrosine from proteins above $90 \mathrm{kDa}$ (Fig.4), including FAK as demonstrated earlier (Fig. 1A).

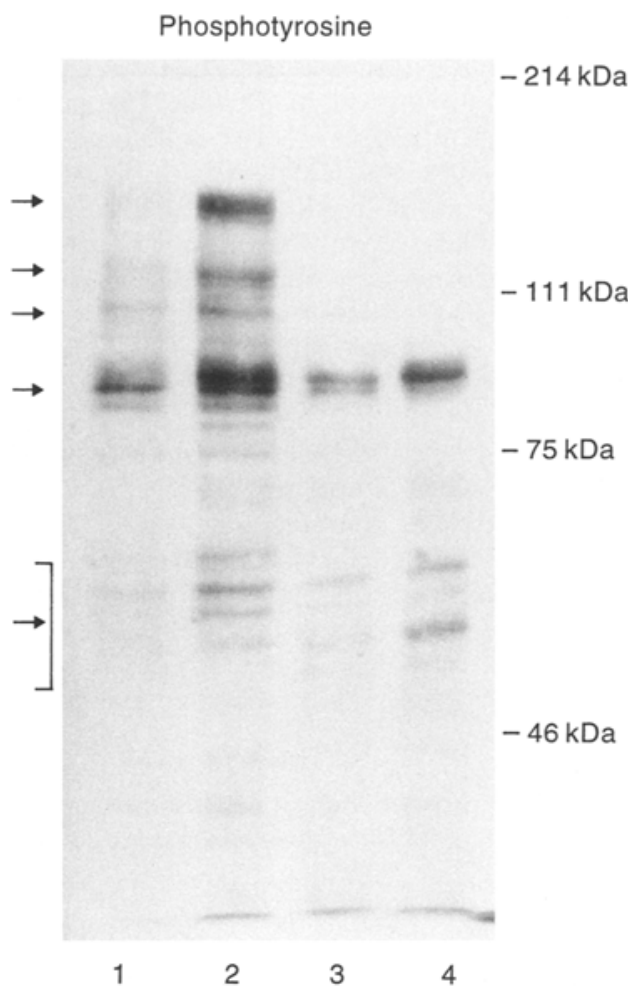

Fig. 4. Phosphotyrosine-containing proteins from glomeruli (lanes 1,2) and glomerular cores (lanes 3,4) isolated from control (lanes 1,3) or STZ-diabetic (lanes 2,4) rats. Total cell lysates $(100 \mu \mathrm{g}$ protein) were separated by SDS-PAGE and transferred to PVDF membranes. Phosphotyrosine-containing proteins were identified with PY20 antibody. Arrows indicate the major proteins at $150 \mathrm{kDa}, 115 \mathrm{kDa}, 105 \mathrm{kDa}$, $90 \mathrm{kDa}$ and between $50 \mathrm{kDa}$ and $60 \mathrm{kDa}$. Results are representative of two individual experiments

Our previous data have shown that mesangial cores can respond to soluble fibronectin with an increased production of PGE [8], and in other cultured cell types plated onto fibronectin elevated tyrosine phosphorylation of FAK has been demonstrated $[13,14]$. We now show that cultured mesangial cells plated for $2 \mathrm{~h}$ onto fibronectin-coated plates have increased PGE production (from $12.76 \pm 1.83$ to $\left.24.52 \pm 1.10 \mathrm{ng} \cdot 2 \mathrm{~h}^{-1} \cdot \operatorname{dish}^{-1} p<0.05, n=3\right)$ and also increased tyrosine phosphorylation of FAK (Fig. $5 \mathrm{~A}$ upper panel). Inhibition of PGE production by preincubation of mesangial cells for $18 \mathrm{~h}$ with $10 \mu \mathrm{mol} / 1$ indomethacin decreased PGE production by $95 \%$. However, phosphorlyation of FAK was only slightly decreased in the indomethacin-treated cells (Fig. $5 \mathrm{~A}$ lower panel).

Culture of mesangial cells in medium with elevated glucose concentrations results in the increased production of fibronectin [2-4]. We have found that 3 weeks of culture in high glucose medium is necessary to consistently observe an increase in fibronectin in both the medium (measured as fibronectin production over the previous $24 \mathrm{~h}$ in serum-free conditions) and in the matrix plus cell-associated fraction 


\section{Phosphotyrosine}

A

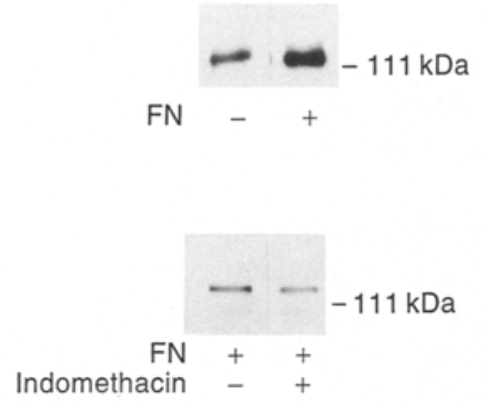

B

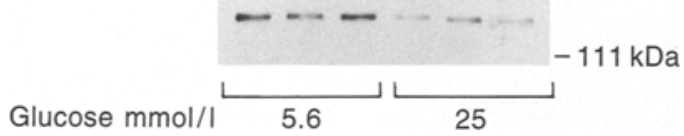

Fig. 5. (A, B) Phosphorylation of FAK in cultured mesangial cells. (A) upper panel. Cultured mesangial cells were plated for $2 \mathrm{~h}$ onto either fibronectin-coated or control plates, phosphorylated FAK was then determined as described previously. Lower panel. Mesangial cells were grown in the presence or absence of $10 \mu \mathrm{mol} / \mathrm{l}$ indomethacin for $18 \mathrm{~h}$ before plating for $2 \mathrm{~h}$ onto fibronectin-coated plates. Phosphorylated FAK was detected as described previously. Results are representative of at least three separate experiments. (B) Mesangial cells were grown for 3 weeks in the presence or absence of $25 \mathrm{mmol} / 1 \mathrm{glu}-$ cose before FAK was isolated and the phosphotyrosine content determined as described previously

(Table 1). Cells grown under these conditions (DMEM $/ 20 \%$ FCS containing $25 \mathrm{mmol} / \mathrm{l}$ glucose) show an increase in PGE production from $38.99 \pm$ 5.85 to $67.20 \pm 8.80 \mathrm{ng} \cdot 24 \mathrm{~h}^{-1} \cdot \operatorname{dish}^{-1}(p<0.05, n=$ $3)$. Surprisingly, although adherent, these cells had a decrease in the tyrosine phosphorylation of FAK (Fig. 5B) when maintained in the above manner. This is in contrast to cells acutely exposed to fibronectin.

\section{Discussion}

This report provides the first demonstration of increased FAK phosphorylation in kidney tissue from a pathological condition, diabetes. Whilst focal adhesions have been repeatedly demonstrated on attachment of cells to a substratum in vitro $[14,18,19]$ they have been difficult to demonstrate in vivo [10]. However, it has recently been shown that focal adhesions (measured by localisation of FAK) are concentrated at the myotendinous junctions [20] and similar experiments using histochemical methods have re-
Table 1. Fibronectin production by mesangial cells cultured in 5.6 or $25 \mathrm{mmol} / 1$ glucose

\begin{tabular}{|c|c|c|c|c|}
\hline \multirow{2}{*}{$\begin{array}{l}\text { Glucose } \\
\text { concen- } \\
\text { tration } \\
(\mathrm{mmol} / \mathrm{l})\end{array}$} & \multicolumn{2}{|c|}{$\begin{array}{l}\text { Cumulative fibronectin } \\
(\mu \mathrm{g} \cdot \mathrm{mg} \text { cellular pro- } \\
\left.\text { tein }^{-1}\right)\end{array}$} & \multicolumn{2}{|c|}{$\begin{array}{l}\text { Released fibronectin } \\
\left(\mu \mathrm{g} \cdot \mathrm{mg}^{-} \text {cellular }\right. \\
\left.\text { protein }{ }^{-1} \cdot 24 \mathrm{~h}^{-1}\right) \\
\end{array}$} \\
\hline & 5.6 & 25 & 5.6 & 25 \\
\hline \multicolumn{5}{|l|}{$\begin{array}{l}\text { Time } \\
\text { (weeks) }\end{array}$} \\
\hline 1 & $290 \pm 70$ & $320 \pm 50$ & $104 \pm 27$ & $60 \pm 7$ \\
\hline 2 & $230 \pm 30$ & $270 \pm 50$ & $103 \pm 18$ & $104 \pm 7$ \\
\hline 3 & $350 \pm 60$ & $510 \pm 40^{a}$ & $150 \pm 19$ & $272 \pm 30^{\mathrm{a}}$ \\
\hline \multicolumn{5}{|c|}{ Data are mean $\pm S E M$} \\
\hline \multicolumn{5}{|c|}{$\begin{array}{l}\text { Cumulative fibronectin was measured in extracts of cells plus } \\
\text { extracellular matrix }\end{array}$} \\
\hline \multicolumn{5}{|c|}{$\begin{array}{l}\text { Released fibronectin was measured in cell supernatants over } \\
24-\mathrm{h} \text { period }\end{array}$} \\
\hline
\end{tabular}

vealed high levels of FAK in developing blood vessels [21]. In the latter paper the authors also noted a concentration of FAK in the mouse glomerulus which appeared to be confined to the capillary loops and the smooth muscle-like mesangial stalk [21]. The mesangial-cell interaction with endothelial cells and/ or glomerular basement membrane at points of mesangial bridging either directly or via the extracellular matrix has been likened to interactions within the myotendenous junction and other similar structures [22]. Thus, a physiological role for focal adhesions (and FAK) in the normal maintenance of mesangial contacts can be envisaged.

We propose that the elevated FAK phosphorylation observed in the diabetic rat glomerulus results from alterations in the extracellular matrix previously reported in diabetes. In addition to the increased fibronectin observed in diabetic kidneys [1] and in cultured mesangial cells [2-4], laminin and type IV collagen $[3,4]$ are also elevated and have all been shown to stimulate phosphorylation of FAK in vitro [14]. It has also been demonstrated that the glycosaminoglycan, hyaluronan, can stimulate FAK phosphorylation although, unlike the matrix glycoproteins, this is not a sustained but a transient response [23]. We have recently demonstrated an increase in the production of hyaluronan by glomerular cores isolated from diabetic rats [24]. FAK phosphorylation is also stimulated by clustering of $\beta_{1}$ subunit-containing integrins [14] and inhibited in cells transfected with deletion mutants of the integrin $\beta_{1}$ chain [25]. In human umbilical vein endothelial cells cultured in high glucose-containing medium, and in vessels isolated from diabetic subjects [26], there is increased expression of $\alpha_{5} \beta_{1}$ integrin, one of the receptors for fibronectin which co-localises within focal adhesions. Thus, the prevailing conditions that develop in the diabetic kidney might support an increase in FAK 
phosphorylation. In the present study the overall phosphotyrosine content of a number of proteins was increased. The mechanism for this is unclear but matrix components have been shown to stimulate increased tyrosine phosphorylation of several cellular proteins besides FAK including other components of focal adhesions such as paxillin $[18,19,23]$.

The phosphorylation of FAK in the diabetic glomerulus appears labile, suggesting that in vivo adhesions may be tenuous. In vitro studies have shown that phosphorylation of FAK is only observed in adherent cells [25], is lost immediately upon detachment of cells from their substratum when focal contacts are disrupted [25], and does not reappear until cells are allowed to reattach $[25,27]$. It is apparent that removal of the Bowman's capsule and epithelial-cell layer to produce a mesangial-enriched glomerular core leads to loss of FAK phosphorylation from diabetic glomeruli suggesting that focal adhesions are disrupted by this procedure. That there was no apparent loss of FAK protein suggests that the cells removed by collagenase digestion do not contribute disproportionately to the overall levels of FAK.

Although diabetes has been associated with increased levels of extracellular matrix proteins, including fibronectin, increased production of prostaglandins (among other biochemical changes) and, as we show here, increased levels of FAK phosphorylation, the question of whether these events can be linked in a signal transduction pathway or whether they occur independently must be addressed. Autophosphorylation of FAK appears the major route of tyrosine phosphorylation of the enzyme [28], resulting in increased kinase activity towards exogenous substrates [13]. Up to now there has been no in vivo exogenous substrate identified for FAK and downstream signalling events are unclear. However, recent work showing association of FAK with cytosolic protein tyrosine kinases $p p 60^{\text {src }}$ and pp59fyn [29], with phosphatidylinositol 3-kinase [30] and with the adaptor protein GRB2 [31], suggests that FAK may have an important signalling role. In addition to FAK, focal adhesions contain structural proteins including vinculin, talin, paxillin and tensin (both paxillin and tensin can be phosphorylated on tyrosine $[18,32]$ and tensin also contains an $\mathrm{SH} 2$ domain [9]) and other kinases including protein kinase $\mathrm{C}$ and src $[9,10]$. Focal adhesions also recruit integrins and the $\beta_{1}$ chain appears essential for the signalling and stimulation of FAK phosphorylation $[14,25]$. However, whether the role of FAK lies solely within the focal adhesion or whether it forms part of wider signalling events is unknown. Although it is not possible to recreate the conditions existing within the kidney glomerulus in vitro, we have investigated some aspects of FAK activation in cultured mesangial cells. Mesangial cells respond to plating onto fibronectin with an increase in FAK tyrosine phosphorlyation, however, cells grown for 3 weeks in high glucose medium which result in an increase in fibronectin content actually showed decreased FAK phosphorylation compared with controls. In preliminary experiments (Clark et al., unpublished data) plating mesangial cells for $2 \mathrm{~h}$ onto matrix derived from mesangial cells grown in $25 \mathrm{mmol} / \mathrm{l}$ glucose for 3 weeks did not lead to an elevation in FAK phosphorylation. All these conditions result in an increase in PGE production. Thus, we may conclude that in vitro, at least in cultured mesangial cells, FAK phosphorylation and presumably activation is not linked directly to PGE production by extracellular matrix components. As fibronectin can interact with a number of other integrins that are not associated with focal adhesions [9] it is possible that signals resulting in prostaglandin production are generated via one of these interactions. Furthermore, although it has recently been demonstrated that eicosanoids $\left(\mathrm{PGF}_{2} \alpha\right.$ and $\mathrm{PGE}_{2}$ ) can stimulate FAK phosphorylation [33], in the present study, blocking PGE production with indomethacin does not appear to influence FAK phosphorylation to any great extent. Finally, it has been shown previously that the effect of fibronectin to elevate prostaglandin levels in the glomerulus is at least partially dependent on protein kinase $C$ [8] as indeed is the increased production of fibronectin induced by high glucose levels [34]. The ability of cells to attach to a substratum and thus form cellular focal adhesions is also a protein kinaseC-dependent event [27]. Future studies on the role of FAK phosphorylation and presumably its kinase activation within this complex signalling network must take into account the role played by protein kinase $\mathrm{C}$.

In conclusion, these studies provide additional support for altered extracellular matrix/cell interactions in the diabetic glomerulus which may contribute to changes within the mesangial cell associated with diabetes. Whether the increased phosphorylation of FAK that we have observed in diabetes contributes directly to subsequent biochemical alterations requires further investigation.

Acknowledgements. The authors would like to thank Dr. T.Parsons and Ms. J.Beitz for antibody 2A7 and helpful advice. We thank Professor R.G. Larkins for critical review of the manuscript. This work was supported by grants from the National Health and Medical Research Council of Australia and Juvenile Diabetes Foundation International.

\section{References}

1. Dixon AJ, Burns J, Dunnill MS, McGee JD (1980) Distribution of fibronectin in normal and diseased human kidneys. J Clin Path 33: 1021-1028

2. Ayo SH, Radnik RA, Garoni JA, Flass WF II, Kreisberg JI (1990) High glucose causes an increase in extracellular matrix proteins in cultured mesangial cells. Am J Path 136: $1339-1348$ 
3. Nahman N Jr, Leonhart KL, Cosio FG, Hebert CL (1992) Effects of high glucose on cellular proliferation and fibronectin production by cultured human mesangial cells. Kidney Int 41: 396-402

4. Pugliese G, Pricci F, Pugliese F et al. (1994) Mechanisms of glucose-enhanced extracellular matrix accumulation in rat glomerular mesangial cells. Diabetes 43: 478-490

5. Schambelane M, Blake S, Sraer J, Bens M, Nivez M-P, Wahbe F (1985) Increased prostaglandin production by glomeruli isolated from rats with streptozotocin-induced diabetes mellitus. J Clin Invest 75: 404-412

6. Bonventre JV, Swidler M (1988) Calcium dependency of prostaglandin $\mathrm{E}_{2}$ production in rat glomerular mesangial cells: evidence that protein kinase $\mathrm{C}$ modulates the $\mathrm{Ca}^{2+}$ dependent activation of phospholipase $\mathrm{A}_{2}$. J Clin Invest 82: $168-176$

7. Williams B, Schrier RW (1993) Glucose-induced protein kinase $\mathrm{C}$ activity regulates arachidonic acid release and prostaglandin production by cultured rat glomerular mesangial cells. J Clin Invest 92: 2889-2896

8. Dunlop M, Keogh R, Larkins R (1993) Fibronectin-induced increase in mesangial cell prostaglandin release: effect of hyperglycemia and PKC inhibition. Diabetes 42 : 183-190

9. Damsky CH, Werb Z (1992) Signal transduction by integrin receptors for extracellular matrix: cooperative processing of extracellular information. Curr Opin Cell Biol 4: $772-781$

10. Sastry SK, Horwitz AF (1993) Integrin cytoplasmic domains: mediators of cytoskeletal linkages and extra- and intracellular initiated transmembrane signaling. Curr Opin Cell Biol 5: 819-831

11. LaFlamme SE, Akiyama SK, Yamada KM (1992) Regulation of fibronectin receptor distribution. J Cell Biol 117: $437-447$

12. Tawil N, Wilson P, Carbonetto S (1993) Integrins in point contacts mediate cell spreading: factors that regulate integrin accumulation in point contacts vs focal contacts. $\mathbf{J}$ Cell Biol 120: 261-271

13. Guan J-L, Shalloway D (1993) Regulation of focal adhesion-associated protein tyrosine kinase by cellular adhesion and oncogenic transformation. Nature 358: 690-692

14. Kornberg L, Earp HS, Parsons JT, Schaller M, Juliano RL (1992) Cell adhesion or integrin clustering increases phosphorylation of a focal adhesion-associated tyrosine kinase. J Biol Chem 267: 23439-23442

15. Kanner SB, Reynolds AB, Vines RR, Parsons JT (1990) Monocloncal antibodies to individual tyrosine-phosphorylated protein substrates of oncogene-encoded tyrosine kinases. Proc Natl Acad Sci (USA) 87: 3228-3332

16. Chang WP, Dimitriadis E, Allen T, Dunlop ME, Cooper M, Larkins RG (1991) The effect of aldose reductase inhibitors on glomerular prostaglandin production and urinary albumin excretion in experimental diabetes mellitus. Diabetologia 34: 225-231

17. Bradford MM (1976) A rapid and sensitive method for the quantitation of microgram quantities of protein utilizing the principle of protein dye binding. Anal Biochem 72: 248-254

18. Burridge K, Turner CT, Romer LH (1992) Tyrosine phosphorylation of paxillin and FAK accompanies cell adhesion to extracellular matrix: a role in cytoskeletal assembly. J Cell Biol 119: 893-903
19. Polanowska-Grabowska R, Geanacopoulos M, Gear ARL (1993) Platelet adhesion to collagen via the $\alpha_{2} \beta_{1}$ integrin under arterial flow conditions causes rapid tyrosine phosphorylation of pp125 $5^{\text {FAK }}$. Biochem J 296: 543-547

20. Baker LP, Daggett DF, Peng HB (1994) Concentration of pp125 focal adhesion kinase (FAK) at the myotendinous junction. J Cell Sci 107: 1485-1497

21. Polte TR, Naftilan AJ, Hanks SK (1994) Focal adhesion kinase is abundant in developing blood vessels and elevation of its phosphotyrosine content in vascular smooth muscle cells is a rapid response to angiotensin II. J Cell Biochem 55: 106-119

22. Takai T, Kriz W (1987) Structural relationship between mesangial cells and basement membrane of the renal glomerulus. Anat Embryol (Berl) 76: 373-386

23. Hall CL, Wang C, Lange LA, Turley EA (1994) Hyaluronan and the hyaluronan receptor RHAMM promote focal adhesion turnover and transient tyrosine kinase activity. $\mathbf{J}$ Cell Biol 126: 575-588

24. Mahadevan P, Larkins RG, Fraser JRE, Fosang AJ, Dunlop MD (1995) Increased hyaluronan prodcution in the glomeruli from diabetic rats: a link between glucose-induced prostaglandin production and reduced sulphated proteoglycan. Diabetologia 38: 298-305

25. Guan J-L, Trevithick JE, Hynes RO (1991) Fibronectin/integrin interaction induces tyrosine phosphorylation of a 120-kDa protein. Cell Regulation 2: 951-964

26. Roth T, Podesta F, Stepp MA, Boeri D, Lorenzi M (1993) Integrin overexpression induced by high glucose and by human diabetes: potential pathway to cell dysfunction in diabetic microangiopathy. Proc Natl Acad Sci (USA) 90: 9640-9644

27. Vuori K, Ruoslahti E (1993) Activation of protein kinase C precedes $\alpha_{5} \beta_{1}$ integrin-mediated cell spreading on fibronectin. J Biol Chem 268: 21459-21462

28. Hildebrand JD, Schaller MD, Parsons JT (1993) Identification of sequences required for the efficient localisation of focal adhesion kinase to cellular focal adhesions. J Cell Biol 123: 993-1005

29. Cobb BS, Schaller MD, Tzeng-Horng L, Parsons JT (1994) Stable association of $p p 60^{\text {src }}$ and $p p 59^{\text {fyn }}$ with the focal adhesion-associated protein tyrosine kinase, pp125 $5^{\mathrm{FAK}}$. Mol Cell Biol 14: 147-155

30. Chen H-C, Guan J-L (1994) Association of focal adhesion kinase with its potential substrate phosphatidylinositol 3kinase. Proc Natl Acad Sci (USA) 91: 10148-10152

31. Schlaepfer DD, Hanks SK, Hunter T, van der Geer P (1994) Integrin-mediated signal transduction linked to Ras pathway by GRB2 binding to focal adhesion kinase. $\mathrm{Na}$ ture 372: 786-791

32. Bockholt SM, Burridge K (1993) Cell spreading on extracellular matrix proteins induces tyrosine phosphorylation of tensin. J Biol Chem 268: 14565-14567

33. Watanabe T, Nakao A, Emerling D et al. (1994) Prostaglandin $F_{2 \alpha}$ enhances tyrosine phosphorylation and DNA synthesis through phospholipase C-coupled receptor via $\mathrm{CA}^{2+}$-dependent intracellular pathway in NIH-3T3 cells. J Biol Chem 269: 17619-17625

34. Studer RK, Craven PA, DeRubertis FR (1993) Role for protein kinase $\mathrm{C}$ in the mediation of increased fibronectin accumulation by mesangial cells grown in high-glucose medium. Diabetes 42: 118-126 